\title{
Microbial Assessment of Yoghurts Sold in Amawbia, Nigeria
}

\author{
Awah Nsikak Sunday ${ }^{1, *}$, Agu Kingsley Chukwuebuka ${ }^{1}$, Muokwe Juliet ${ }^{1}$, Irondi Chidiebere ${ }^{1}$, \\ Okeke Chidi Benjamin ${ }^{1}$, Anaukwu Chikodili Gladys ${ }^{1}$, Archibong Etim Joseph ${ }^{1}$, Iloanusi Confidence Ada ${ }^{1}$, \\ Ngenegbo Uche ${ }^{2}$, Umeoduagu Nnamdi ${ }^{3}$
}

\author{
${ }^{1}$ Department of Applied Microbiology and Brewing, Nnamdi Azikiwe University, PMB 5025, Awka, Nigeria \\ ${ }^{2}$ Department of Parasitology and Entomology, Nnamdi Azikiwe University, PMB 5025, Awka, Nigeria \\ ${ }^{3}$ Department of Microbiology, Tansian University, Nigeria
}

Copyright $\bigcirc 2016$ by authors, all rights reserved. Authors agree that this article remains permanently open access under the terms of the Creative Commons Attribution License 4.0 International License

\begin{abstract}
Five brands yoghurts designated A, B, C, D and $\mathrm{E}$ were obtained and used for assessing their microbial quality. A ten-fold serial dilution was carried out and appropriate dilution used to inoculate duplicate plates of SDA, Eosin methylene blue, MacConkey and Nutreint agars. Discrete colonies that developed were purified and stored on agar slant at $4^{\circ} \mathrm{C}$. The $p \mathrm{H}$ of the samples ranged from 5.6 to 6.0. In the total coliform count, sample A recorded no count while others had count from 2.0 to $5.0 \times 10^{2} \mathrm{cfu} / \mathrm{ml}$. The total viable bacterial and fungal counts were 6.0 to $18.0 \times 10^{4}$ and 1.0 to $6.0 \times 10^{3} \mathrm{cfc} / \mathrm{ml}$, respectively. Five fungal genera were obtained as Aspergillus, Penicillium, Fusarium, Mucor, Geotricum, Neurospora and Absidia. Mucor species occurred in all the samples while Fusarium species occurred only in sample B. Among the samples, yoghurt sample B harbored a greater percentage of the fungal isolates. Samples $\mathrm{C}$ and $\mathrm{D}$ had the least number of fungal of three (3) each. The bacterial isolates obtained include species of Staphylococcus, Lactobacillus, Escherichia, Bacillus, Pseudomonas and Klebsiella. Sample B also recorded the highest number of bacterial isolates. The genera Bacillus occurred in all the yoghurt samples whereas Lactobacillus and E.coli occurred only in two yoghurt samples each.
\end{abstract}

Keywords Yoghurt, Fungi, Bacteria, Awka, Contaminants, Quality Assessment

\section{Introduction}

Yoghurt is a cultured dairy product produced by the lactic acid fermentation of milk using a combination of bacteria such as Lactobacillus delbruekii subsp. bulgaricus and Streptococcus salivarius subsp. thermophilus in the ratio of 1:1 [1]. Yoghurt is made from skimmed milk usually from cows, sometimes from other animals such as goat or sheep
[2]. Milk from which yoghurt is made is an excellent source of protein, vitamins and minerals like calcium and some antibacterial substances such as lysozyme and lactoperoxidase, as well as large amount of lactose sugar, peptone, phosphate and nitrogen-based enzymes [3].

The milk used in yoghurt production is homogenized, heated to a temperature of between $85-100^{\circ} \mathrm{C}$ and then cooled to $41-45^{\circ} \mathrm{C}$. The special starter cultures, Streptococcus salivarius subsp.thermophilus and Lactobacillus delbruekii subsp.bulgaricus are then added [4]. The yoghurt is incubated for 3 hours at a temperature of $40^{\circ} \mathrm{C}$ [2]. The relationship between the two starter organisms is known as proto-cooperation, that is, they have a mutually favorable interaction but are not completely interdependent. Both grow in milk on their own, but they grow and produce acidity faster when there is availability of peptide and free amino acids [5]. The acids produced as well as acetaldehyde and diacetyl give the product its unique smooth texture, tart flavor and aroma [6].

Yoghurt has been described as a notoriously balanced food containing almost all the nutrients present in milk but in a more assailable form [7]. Microorganisms present in fermented dairy products stabilize bowl microflora. The health claims associated with the consumption of yoghurt include alleviation of lactose intolerance, lowering of serum cholesterol level, treatment of diarrhea and possibility of exhibiting anticancer activity [8]. Yoghurt can be consumed as both food and thirst quenching beverage [3].

Yoghurt due to its high nutritive value is susceptible to contamination by pathogenic microorganisms causing spoilage [9]. Molds and yeasts are the primary contaminants in yoghurt produced commercially in Nigeria. They are responsible for off-flavor, loss of texture quality due to gas production and package swelling and shrinkage [10]. Molds and yeasts growing in yoghurt utilize some of the acids and produce a corresponding decrease in the acidity, which may favor the growth of putrefactive bacteria [11]. Coliform 
bacteria can contaminate yoghurt through water and poor hygiene of the production and processing environment [12]. Further contamination of yoghurt by microorganisms can occur during milking, handling, storage and other processing processes, clearing and handling of milking utensils [13]. This study was intended to assess microbial quality of yoghurt samples sold in Awka Metropolis, Nigeria.

\section{Materials and Methods}

\section{Sample Collection}

Five different brands of Nigerian-manufactured yoghurts produced by different yoghurt manufacturing factories designated as A, B, C, D and E, manufactured between January 4 to January 25, 2016, were randomly purchased from different provision stores in Amawbia Metropolis, Nigeria and used for the investigation between February 6 to March 6, 2016.

\section{Microbiological Analyses}

All the media Nutrient Agar (NA), MacConkey (MA), Sabouraud Dextrose (SDA) and Eosin Methylene Blue (EMB) agars were reconstituted according to manufacturer's specifications and sterilized in the autoclave at $121^{\circ} \mathrm{C}$ for 15 minutes. Nystatin, an antifungal drug was incorporated into Nutrient and MacConkey agars in order to inhibit fungal growth in those cultures. Chloramphenicol, an antibacterial drug was incorporated into SDA to inhibit bacterial growth in the fungal plates. A ten-fold serial dilution of the different yoghurt samples was carried out. Using the pour plate method, appropriate dilutions were used to inoculate duplicate plates of the different growth medium. The plates were incubated at room temperatures for $48-72$ hours. The microbial colonies that developed were counted and recorded. Each of the discrete colonies that developed was sub-cultured and the pure cultures obtained were stored on agar slopes. The agar slopes were maintained in the refrigerator at $4^{0} \mathrm{C}$ and used for the various identification techniques. The $p \mathrm{H}$ of the different yoghurt samples was determined. The bacterial isolates were characterized based on microscopic appearance, colony morphology and biochemical characteristics. The fungal isolates were characterized based on colonial morphological features and microscopic examination using the Lactophenol cotton blue stained slide cultures and the results compared with fungal atlas [14].

\section{Results}

The results of the microbial count and $p \mathrm{H}$ determination of the yoghurt samples are shown in Table 1.The total aerobic count ranges from $1.0 \times 10^{3}$ to $18.0 \times 10^{4} \mathrm{CFU} / \mathrm{ml}$. Among the samples, the total coliform counts ranged between 2.0 and $5.0 \mathrm{CFU} / \mathrm{ml}$ while the total fungal count ranged between 1.0 and $6.0 \times 10^{4} \mathrm{CFU} / \mathrm{ml}$. The $p \mathrm{H}$ was between 7.1 and 7.9.
Table 2 shows the fungal isolates of the different yoghurt samples. They include species of Aspergillus, Penicillium, Fusarium, Mucor, Geotrichum, Neurospora and Absidia. Mucor sp. was present in all the samples while Fusarium sp. was present in only one of the samples. Samples C and D had the same number of bacterial isolates. This was followed in order of magnitude by Samples A, E and B. The bacterial isolates as presented in Table 3 were characterized based on morphological and biochemical characteristics as belonging to the genera Staphylococcus, Bacillus, Lactobacillus, Escherichia, Pseudomonas and Klebsiella. Yoghurt sample A had the highest number of bacteria isolated closely followed sample C. Samples A, D and E had the same number of bacteria isolated. Bacillus specie was present in all the samples while Staphylococcus specie was present in only two samples.

Table 1. Microbial Counts and $\mathrm{pH}$ of Yoghurt Samples

\begin{tabular}{|c|c|c|c|c|}
\hline Sample & $\mathrm{pH}$ & $\begin{array}{c}\text { Total coliform } \\
\text { count }(\mathrm{x} \mathrm{102} \\
\mathrm{cfu} / \mathrm{ml})\end{array}$ & $\begin{array}{c}\text { Total bacterial } \\
\text { count(x } \\
104 \mathrm{cfu} / \mathrm{ml})\end{array}$ & $\begin{array}{c}\text { Total fungal } \\
\text { count } \\
(\mathrm{x} 103 \mathrm{cfu} / \mathrm{ml})\end{array}$ \\
\hline $\mathrm{A}$ & 5.60 & - & 18.0 & 1.0 \\
\hline $\mathrm{B}$ & 5.68 & 3.0 & 6.0 & 6.0 \\
\hline $\mathrm{C}$ & 5.85 & 5.0 & 8.0 & 2.0 \\
\hline $\mathrm{D}$ & 5.91 & 4.0 & 10.0 & 3.0 \\
\hline $\mathrm{E}$ & 6.00 & 2.0 & 13.0 & 4.0 \\
\hline
\end{tabular}

Table 2. Fungal Isolates from the Yoghurt Samples

\begin{tabular}{|c|c|c|c|c|c|}
\hline Fungal species & $\mathrm{A}$ & $\mathrm{B}$ & $\mathrm{C}$ & $\mathrm{D}$ & $\mathrm{E}$ \\
\hline Aspergillus & + & + & + & + & - \\
\hline Penicillium & - & + & + & - & + \\
\hline Fusarium & - & + & - & - & - \\
\hline Fusarium & + & + & + & + & + \\
\hline Geotrichum & + & - & - & + & + \\
\hline Neurospora & - & + & - & - & + \\
\hline Absidia & + & + & - & - & + \\
\hline
\end{tabular}

Key: + Present; - Absent

Table 3. Bacteria Isolated from Yoghurt Samples

\begin{tabular}{|c|c|c|c|c|c|}
\hline & \multicolumn{5}{|c|}{ Yoghurt Sample } \\
\hline Bacterial isolates & $\mathrm{A}$ & $\mathrm{B}$ & $\mathrm{C}$ & $\mathrm{D}$ & $\mathrm{E}$ \\
\hline Staphylococcus & - & + & - & - & + \\
\hline Lactobacillus & + & - & + & - & - \\
\hline Escherichia & - & + & - & + & - \\
\hline Bacillus & + & + & + & + & + \\
\hline Pseudomonas & + & + & + & + & - \\
\hline Klebsiella & - & + & + & - & + \\
\hline
\end{tabular}

\section{Discussion}

Table 1 shows the microbial counts and $p \mathrm{H}$ of the five yoghurt samples analyzed. The $p \mathrm{H}$ of all the samples 
analyzed fell within the range of acidity 5.6 to 6.0 . Acidic $p \mathrm{H}$ of 5.5 averages inhibits most potential pathogenic organisms. This $p \mathrm{H}$ value also correlates with the $p \mathrm{H}$ of acetic acid and lactic acid [15]. The total viable count for bacterial isolates ranges between $6.0 \times 10^{4}$ to $18.0 \times 10^{4} \mathrm{cfu} / \mathrm{ml}$, for coliforms $2.0 \times 10^{4}$ to $5.0 \times 10^{2} \mathrm{cfu} / \mathrm{ml}$, while the fungal isolates ranges between $1.0 \times 10^{3}$ to $6.0 \times 10^{3} \mathrm{cfu} / \mathrm{ml}$.

The result of the fungal isolates (Table 2) showed that the products harbor various fungi species which include Aspergillus, Pencillium, Fusarium, Mucor, Geotrichum, Nuerospora and Absidia. Of all the isolates present, Mucor specie was the most predominant contaminant. The presence of Mucor speciein the yoghurt analyzed may be due to their rapid colonization and utilization of food substances present. This might be responsible for their rapid proliferation [10]. Aspergillus species present in food substances including yoghurt are noted to produce toxins including aflatoxins which when consumed by man or animals affects mostly the liver [16].

Table 3 shows the bacterial isolates from the yoghurt samples. The species isolated include Staphylococcus, Lactobacillus, Escherichia, Bacillus, Pseudomonas and Klebsiella. These bacterial isolates obtained conform with our earlier report except that Lactobacillus was not isolated from the previous work [17]. Species of Bacillus was observed as the most predominant bacterial contaminant. This could be because of easy distribution of their spores in the environment. Also their spores can withstand harsh environmental conditions, which could be responsible for their proliferation and contamination of milk products [18]. Improper handling, processing and packaging could lead to a high rate of Bacillus species which are potential agents of food poisonings [19]. The presence of the starter cultures Streptococcus thermophilus and Lactobacillus bulgaricus are desirable because they are responsible for flavor, aroma and fermentation of milk for yoghurt production [20]. The presence of Staphylococcus specie in the product could also be as a result of processing, handling and packaging since they are often found on the outer surface of the body [21]. The isolation of coliforms may be as a result of poor environmental conditions due to dust and contamination of the water used as raw material [22-27].

\section{Conclusions}

The yoghurt brands according to the result of the investigation clearly signify that they are not of the same microbial quality. These differences may be due to improper sanitary conditions during production processes. It may also be as a result of using unhealthy cows. To overcome the problem of microbial contamination and its associated problems, only healthy cows should be milked. Also the udder of the cow should be well cleaned and the handlers should thoroughly wash their hands before milking. The milking utensils should also be kept clean. More importantly, during processing high level of cleanliness should be maintained to ensure that the products are of good quality.

\section{Acknowledgements}

We acknowledge the efforts of the entire Laboratory Staff of Microbiology Department, Nnamdi Azikiwe University, Awka, for helping out with the preparation of the culture media for the Microbiological Analyses of the various micro organisms isolated in this study.

\section{REFERENCES}

[1] Y. H. Hui. Yoghurt Manufacturing. Encyclopedia of Food Science and Technology, Vol.4, 1905-2907, 1992.

[2] I. Miller, H. Martin, O. Kandler. The Spectrum of Amino Acids in Yoghurt. Milch Wissenschaft, Vol.19, 18-25, 1964.

[3] A. B. Alfa-Lawal. Dairy and Food Engineering. Methods of Yoghurt production. Division of Lundane, Sweeden, 177, 1984.

[4] P. J. Kroger. Quality of Yoghurt. Journal of Dairy Science, Vol.59, 344-350, 1976.

[5] A. Y. Tamine, K. Robinson. Yoghurt Science and Technology. Published by Institute of Applied Science. 32-56, 2004.

[6] P. J. Fellow. Food Processing Technology, $2^{\text {nd }}$ Edition, Woodhead Publishing, Cambridge, 2000.

[7] I. H. Anthar.. Preparation of Cheese and Yoghurt at Household Level. Pakistan Agricultural Council, Islambad. 390 -391, 1986.

[8] S.C. Nickerson. Control of Mastitis Today and Tomorrow. Dairy Research Report. Hill Farm Research Report. Louisiana State University, Homer, Louisiana, USA, 1-4, 1994.

[9] J.T. Nickerson, A.J. Sinskey. Microbiology of Foods and Food Processing. New York: Elsevier, North Holland. 92, 1972.

[10] V. R. Suriyarachichi, G. H. Fleet. Occurrence and Growth of Yeast in Yoghurt. Journal of Applied Environmental Microbiology, Vol.42, 572-57, 1981.

[11] W. C. Frazier, D. C. Westhoff. Food Microbiology. $3^{\text {rd }}$ Edition, Taht McGrawHill, New Delhi, India. pp. 279-299, 1989.

[12] M. R. Adams, M. O. Mosa. Food Microbiology. Royal Society Chemistry, England. 265, 1990.

[13] P. H, Miller, J. H. Kim, O. P. Juy. Cheese and Yoghurt Production. Marcel Better Inc, New York 63-71, 1997.

[14] D. Ellis, S. Davis, H. Alexiou, R. Handke, R. Bartley. Descriptions of Medical Fungi, $2^{\text {nd }}$ Edition, Nexus Print Solutions, Adelaide, Australia, 2007.

[15] K. C. Chung, J. M. Geopfert. Growth of Salmonella at low pH. Journal of Food Science, Vol.35, 326 -328, 1970.

[16] D. McDonagh, F. Lawless, E. Gardiner, Ross, R. P. Ross, C. Stanton, W. J. Donnelly. Milk and Diary Product for Better Human Health. Diary Quality Department, DPRC, Moorepark, 
England. 14-16, 1997.

[17] K.C. Agu, E. J. Archibong, D. C. Anekwe, Ago, C. A. Ago, A. C. Okafor, N. S. Awah. Assessment of Bacteria Present in Yoghurt Sold in Awka Metropolis. Scholars Journal of Applied Medical Sciences, Vol.2 (6D): 3071-3075, 2014.

[18] V. Umoh. Contamination of "Fura da nono" by Staphylococci and Growth of an Enterotoxigenic Staphylococcus aureus in Fura. Zaria Vetenary, Vol.4, No.2, 53-58, 1989.

[19] D. L. Antai, J. E. Kuenberg. Incidence and Cost of Food Borne Diarrhoeal Disease in United States. Journal of Food Product, 48: $887-890,1985$.

[20] A. Trema, A. Musa. Soybeans Yoghurt Production. Nigerian Journal of Biotechnology, Vol.9, 17-32, 1998.

[21] M. L. Prescott, S. P. Harley, A. D Klein. Microbiology. M.C. Brown Publisher, Dubuque. 951-952, 2004.

[22] K. A. Talaro. Foundation in Microbiology. M.C. Brown Publisher, Dubuque 781-783, 2006.

[23] A.E. Mbachu, C.A. Etok, K.C. Agu, O.I. Okafor, N.S. Awah, L.C. Chidi-Onuorah, V.C. Ekwueme, J. Okpala, M.O. Ogbue, M.O. Ikele. Microbial Quality Of Kunu Drink Sold in Calabar,
Cross River State, Nigeria. Journal of Global Biosciences, Vol. 3, No. 2, 511-515, 2014

[24] B.C. Okeke, K.C. Agu, P.O. Uba, N.S. Awah, C.G. Anaukwu, E.J. Archibong, L.I. Uwanta,, J.N Ezeneche, C.U. Ezenwa, M.U. Orji. Wine Production from Mixed Fruits (Pineapple and Watermelon) Using High Alcohol Tolerant Yeast Isolated from Palm Wine. Universal Journal of Microbiology Research, Vol.3, No. 4, 41-45, 2015.

[25] C.G. Anaukwu, G.O. Ugwuoke, I.A. Ekwealor, O.C. Okafor, K.C. Agu. American Journal of Life Science Researches, Vol.3, No.4, 282-286, 2015.

[26] K.C. Agu, M.U. Orji, Onuorah, S.C.,Onuorah, S.O. Egurefa, C.G. Anaukwu, U.C. Okafor, N.S. Awah,, O.I. Okafor, A.E. Mbachu, B.C. Anyaegbunam. Comparative Bacteriological Analysis of Ready-to-Eat Vegetables Salad Sold by Various Food Vendors in Awka American Journal of Life Science Researches, Vol.2, No.4, 458-465, 2014.

[27] C.G. Anaukwu, F.C. Nwangwu, O.I. Okafor, C.C. Ezemba, C.C. Orji, K.C. Agu, E.J. Archibong. Microbiological analysis of Burukutu beverage produced in southern part of Nigeria. European Journal of Experimental Biology, Vol.5, No.8, $18-22,2015 . s$ 